\title{
PENGARUH WORD OF MOUTH TERHADAP MINAT BERKUNJUNG PEMUSTAKA PADA PERPUSTAKAAN DAERAH SALATIGA
}

\author{
Anton Hermawan ${ }^{1 *}$ \\ Program Studi Ilmu Perpustakaan, Universitas Kristen Satya Wacana Salatiga \\ Jalan Diponegoro 52-60, Salatiga, Jawa Tengah \\ ${ }^{*}$ Korespondensi: anton.hermawan@staff.uksw.edu
}

\begin{abstract}
[Effect Word of Mouth to interest to visit reader to regional libraries in Salatiga] Libraries as information resources and science, not only collected, processed, and saved but needs to disseminated review to public. Efforts to review disseminate the existence of Libraries not limited to the conventional way of marketing, but can be through word of mouth. It is expected that increasing interest in visiting to library. Therefore, researchers interested in researching the relationship between word of mouth with interest to visit the library. Analysis used statistic deskriptif and simple linear regression. Data were processed using SPSS 22. The result of the study showed there was effect of word of mouth to interest to visit the library.
\end{abstract}

Keywords: word of mouth; interest to visit; regional library; information resources; science

\begin{abstract}
Abstrak
Perpustakaan sebagai sumber informasi dan ilmu pengetahuan tidak hanya dihimpun, diolah, dan disimpan namun perlu untuk disebarkan kepada masyarakat. Upaya untuk menyebarluaskan keberadaan perpustakaan tidak terbatas pada cara pemasaran konvensional (umum), tetapi dapat melalui berita dari mulut ke mulut. Diharapkan melalui cara tersebut minat berkunjung ke perpustakaan dapat meningkat. Oleh karena itu, peneliti tertarik untuk meneliti hubungan antara WOM dengan minat berkunjung pada perpustakaan. Analisa menggunakan statistic deskriptif dan regresi linier sederhana. Data yang diperoleh diproses menggunakan SPSS 22. Hasil yang diperoleh menunjukkan bahwa terdapat pengaruh berita dari mulut ke mulut terhadap minat berkunjung ke perpustakaan.
\end{abstract}

Kata kunci: berita dari mulut ke mulut; perpustakaan daerah; sumber informasi; ilmu pengetahuan

\section{Pendahuluan}

Perpustakaan sebagai sumber informasi dan ilmu pengetahuan tidak hanya menghimpun, mengolah, dan menyimpan bahan pustaka, namun perlu untuk menyebarkan bahan pustaka kepada masyarakat. Hal ini terkait dengan tujuan perpustakaan antara lain, menyediakan informasi dalam meningkatkan pengetahuan keterampilan dan kesejahteraan, menyediakan informasi yang murah, mudah cepat dan tepat, upaya pengembangkan dan pemberdayaan masyarakat melalui penyediaan bahan pustaka dan informasi, sebagai pusat kehidupan budaya, serta memfasilitasi masyarakat untuk belajar sepanjang hayat (Hermawan dan Zulfikar, 2006: 31). Dalam upayanya tersebut, khususnya perpustakaan umum, telah melakukan pengembangan layanan berbasis teknologi informasi, melalui layanan pendidikan, layanan informasi dan bahkan layanan rekreatif. Diharapkan dengan pengembangan layanan yang dilakukan, mampu meningkatkan pemanfaatan perpustakaan, Peningkatan pemanfaat perpustakaan ini dirasa penting karena terkait dengan tujuan perpustakaan dalam mencerdaskan dan mensejahterakan bangsa. Selain itu mengingat turunnya minat baca negara berkembang tidak terkecuali di Indonesia. 
Supriyanto (2006: 29), menyebutkan dalam penelitian yang dilakukan oleh World Bank dalam "Education in Indonesia-From Crisis to Recovery" digambarkan bahwa tingkat minat baca siswa SLTP, SMA dan SMK di Indonesia rendah, ironisnya lagi, ternyata di kalangan perguruan tinggi juga masih sedikit yang mempunyai kebiasaan membaca yang baik. Data ini diperkuat oleh UNESCO pada 2012 yang menyebutkan bahwa indeks minat baca di Indonesia hanya mencapai 0,001. Artinya, dari 1.000 penduduk, hanya satu warga yang tertarik untuk membaca. Menurut indeks pembangunan pendidikan UNESCO, Indonesia berada di nomor 69 dari 127 negara. Dari fakta tersebut dapat disimpulkan bahwa, dengan rendahnya minat membaca, hal ini tentunya berdampak terhadap kunjungan masyarakat ke perpustakaan, khususnya Perpustakaan Daerah.

Kurangnya minat masyarakat berkunjung ke Perpustakaan Daerah yang umum terjadi di beberapa daerah, ternyata hal ini tidak terjadi dengan Perpustakaan Daerah Salatiga. Dari data yang diperoleh dari kantor Perpustakaan dan Arsip Daerah Kota Salatiga (2016), setelah mengalami pindah lokasi, renovasi gedung dan perbaikan fasilitas, tingkat kunjungan perpustakaan mengalami kenaikan yang cukup signifikan, tahun 2012 sebesar 12.950 pengunjung, di tahun 2013 naik menjadi 293.810 pengunjung, 355.032 pengunjung di tahun 2014, dan 360.000 pengunjung ditahun 2015. Hal ini dikategorikan cukup tinggi dengan kota yang memiliki populasi 190.000 jiwa. Selain komitmen dari Pemerintah Daerah terhadap penyediaan fasilitas bagi Perpustakaan dan Arsip Daerah Salatiga, peneliti juga mengamati adanya fenomena komunikasi pemasaran yang terjadi dalam masyarakat terkait keberadaan Perpustakaan Daerah Salatiga tersebut. Komunikasi pemasaran tersebut adalah word of mouth (WoM) atau berita dari mulut ke mulut mengenai keberadaan PERPUSDA Salatiga, sehingga menarik minat untuk berkunjung ke Perpustakaan Umum Daerah Salatiga.

Beberapa peneliti mengungkapkan bahwa, komunikasi pemasaran dari mulut ke mulut atau getok tular (WoM) dinilai cukup efektif. Menurut Kotler dan Keller (2007: 204), berita dari mulut ke mulut atau word of mouth merupakan proses komunikasi yang berupa pemberian rekomendasi baik secara individu maupun kelompok terhadap suatu produk atau jasa yang bertujuan untuk memberikan informasi secara personal. Sedangkan Rangkuti (2009: 77), mendefinisikan berita dari mulut ke mulut (word of mouthWoM) sebagai usaha pemasaran yang memicu pelanggan untuk membicarakan, mempromosikan, merekomendasikan, dan menjual suatu produk/ jasa atau merk kepada pelanggan lain.

Dalam penelitiannya Bansal et al (2000: 166-177) mengungkapkan bahwa komunikasi melalui word of mouth terbukti lebih efektif dalam menyampaikan informasi dan lebih berpengaruh terhadap minat beli konsumen daripada promosi iklan. Sepaham dengan Bansal, Lupiyoadi (2013: 182) menyebutkan bahwa word of mouth (WoM) dikenal mempunyai pengaruh dan dampak yang besar terhadap pemasaran produk/ jasa dibanding dengan aktifitas komunikasi lainnya. Penelitian yang dilakukan Ujianto (2013 : 74) berjudul Strategi Word of Mouth Communication dalam Meningkatkan Minat Menonton Kesenian Banyumasan, menyimpulkan bahwa komunikasi mulut ke mulut mampu mempengaruhi masyarakat dalam menyaksikan pertunjukan seni dikarenakan adanya promosi yang meyakinkan, atau jika tidak karena masyarakat membuktikan sendiri kebenaran iklan/ promosi dari 
keunggulan produk tertentu. Selain itu, seseorang jauh lebih percaya dari rekomendasi orang yang sudah lama dikenalinya misal keluarga, tetangga, teman, ataupun kerabat yang lain. Lebih dalam lagi, penelitian word of mouth terkait dengan minat beli yang dilakukan oleh Kumala (2012), mendapatkan fakta bahwa terdapat pengaruh antara word or mouth terhadap minat beli konsumen pada Tune Hotels Kuta Bali. Pengaruh yang ditimbulkan oleh word of mouth ternyata signifikan sehingga dapat dikatakan bahwa semakin tinggi word of mouth yang terjadi, maka semakin tinggi juga minat beli konsumen. Hasil yang hampir sama juga ditunjukan oleh penelitian yang dilakukan oleh Sari (2012), disimpulkan bahwa terdapat pengaruh electronic word of mouth (eWoM) di social media twitter terhadap minat beli konsumen pada restoran holycowsteak.

Dari penjelasan tersebut peneliti tertarik untuk melakukan penelitian mengenai pengaruh word of mouth terkait dengan minat berkunjung ke Perpustakaan Umum Daerah (PERPUSDA) Salatiga. Penelitian ini dipilih dikarenakan masih sedikitnya penelitian mengenai word of mouth yang dikaitkan dengan sektor jasa (nirlaba) khususnya perpustakaan. Dalam penelitian ini peneliti menggunakan konsep pengukuran yang diungkapkan oleh Godez dan Mayzlin (2004). Dalam pengukuran tersebut Godez dan Mayzlin menggunakan dua elemen untuk mengukur word of mouth yaitu volume dan dispersion.

\section{Rumusan Masalah}

Dalam penelitian tentang word of mouth dalam lingkup pemasaran jasa, khususnya perpustakaan, peneliti mengangkat permasalahan penelitian sebagai berikut:

Adakah pengaruh antara informasi yang diperoleh melalui word of mouth terhadap minat berkunjung pada Perpustakaan Daerah Salatiga?

\section{Tinjauan Pustaka}

\section{Word of Mouth}

Menurut Lupiyoadi (2013: 178), organisasi dalam mengkomunikasi produk/ jasa dapat melalui iklan, penjualan pribadi, promosi penjualan, hubungan masyarakat surat langsung (direct mail) dan informasi dari mulut ke mulut (word of mouth/WoM). Hal ini senada dengan Hermawan (2012), yang menyebutkan bahwa salah satu cara dalam mengkomunikasikan produk/ jasa, yaitu melalui berita dari mulut ke mulut (Word of Mouth/ WoM). Silverman (2001: 25) mengatakan bahwa word of mouth adalah komunikasi tentang produk dan jasa antara orang-orang yang dianggap independen dari perusahaan yang menyediakan produk dan jasa, dalam suatu media yang dianggap independen dari perusahaan. Menurut Ali (2010: 32) word of mouth adalah upaya untuk memberikan alasan agar orang berbicara tentang merk, produk maupun jasa dan membuat berlangsungnya pembicaraan itu menjadi lebih mudah. Pernyataan yang hampir sama diungkapkan oleh O'Leary dan Sheehan (2008:2), menyebutkan bahwa word of mouth adalah proses pertukaran informasi, terutama rekomendasi tentang produk dan layanan, antara dua orang 
dengan cara yang informal. Menurut Ulumi et al (2014), word of mouth dikenal sebagai alat yang kuat untuk memasarkan atau mempromosikan produk atau perusahaan tanpa biaya ataupun dengan biaya yang sangat kecil. Selain itu, word of mouth juga merupakan strategi promosi yang paling kuat, murah, efektif yang dapat digunakan dalam bisnis. Dari uraian tersebut dapat disimpulkan bahwa, word of mouth pada dasarnya merupakan informasi dalam bentuk pesan lisan mengenai produk atau jasa, bahkan perusahaan itu sendiri, yang pernah dialami oleh pembeli yang kemudian disampaikan kepada orang lain dengan cara informal.

\section{Proses Word of Mouth ( WoM )}

Berbicara mengenai minat beli terhadap suatu barang atau jasa, tidak terlepas dengan studi mengeai perilaku konsumen. Schiffman dan Kanuk (2000) mendefinisikan studi perilaku konsumen sebagai cara individu mengambil keputusan untuk memanfaatkan sumber daya mereka yang tersedia (waktu, uang, usaha) guna membeli barang-barang yang berhubungan dengan konsumsi. Schiffman dan Kanuk berpendapat bahwa proses pengambilan keputusan dapat melalui tiga tahapan yang berbeda namun berhubungan satu sama lain, yaitu tahap masukan (input), tahap proses, dan tahap keluaran (output). Dalam tahap masukan, pengenalan konsumen terhadap kebutuhan dipengaruhi oleh usaha pemasaran perusahaan (produk, harga, saluran distribusi dan promosi) dan pengaruh sosial eksternal antara lain: keluarga, teman, tetangga, sumber informasi dan non komersial lain, kelas sosial, dsb. Tahap proses dalam hal ini memfokuskan pada bagaimana cara konsumen mengambil keputusan. Kemudian tahap keluaran, terkait perilaku konsumen dalam membeli produk/ jasa atas motif percobaan atau pembelian ulang, dan evaluasi setelah membeli. Sedangkan Shett, et al (1999), mengemukan mengenai tahap dalam proses pengambilan keputusan yaitu: pengenalan masalah, pencarian informasi, evaluasi alternatif, pembelian dan perilaku setelah (purna) pembelian. Hal ini dapat digambarkan dalam skema berikut:

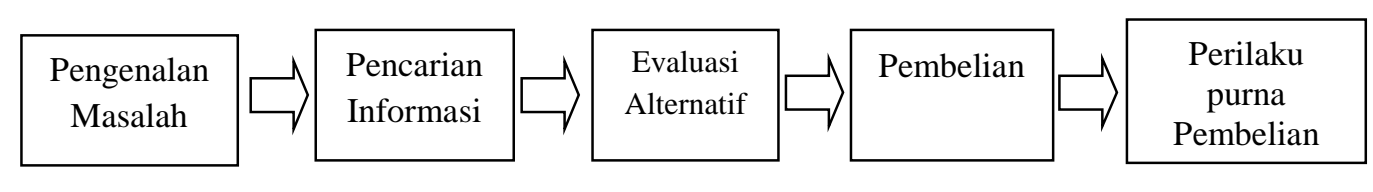

Gambar 1. Model Perilaku Konsumen (Shett, et al,1999)

Lebih sederhana lagi, Mowen dan Minor (2002), mengungkapkan bahwa proses perilaku konsumen dalam mengambil keputusan terdiri dari tiga tahap yaitu: adanya stimulus-stimulus/ rangsangan pemasaran (marketing stimuli), kotak hitam (black box) dan diakhiri dengan respon konsumen. Dalam proses diperlihatkan bahwa stimulus-stimulus pemasaran (marketing stimuli) mampu mempengaruhi respon pelanggan, dimana diantara marketing stimuli dan respon terdapat kotak hitam (black box). Kotak hitam merupakan variable intervensi seperti suasana hati, pengetahuan konsumen, sikap, nilai dan situasi yang dihadapi konsumen. Tahap ketiga merupakan respon konsumen yang dapat berupa tindakan 
membeli atau tidak membeli produk/jasa yang ditawarkan. Berikut digambarkan mengenai model perilaku konsumen yang sederhana menurut Mowen dan Minor (2002).

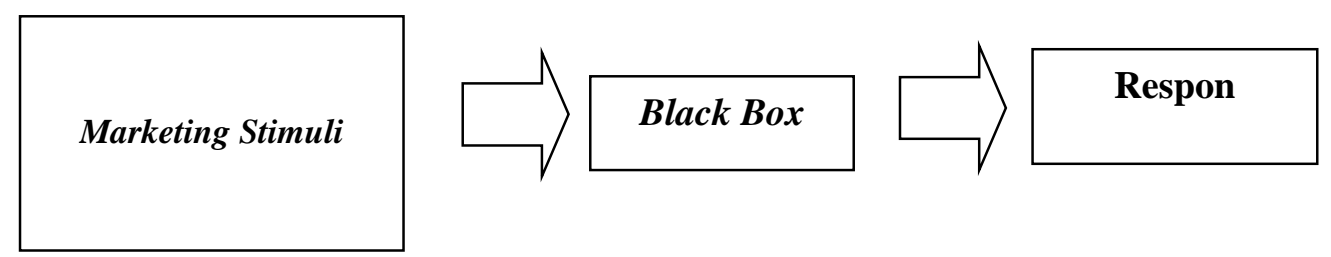

Gambar 2. Model Perilaku Konsumen yang Sederhana (Mowen dan Minor, 2002)

Dari beberapa pendapat ahli tersebut, peneliti dapat menarik kesimpulan terkait dengan proses pengambilan keputusan konsumen dalam membeli barang/ jasa. Tahap pertama merupakan pengenalan masalah yang terjadi ketika dirasakannya kebutuhan atas produk / jasa (Mowen dan Minor, 2002). Kemudian proses selanjutnya konsumen akan memulai mencari informasi mengenai kebutuhan yang dirasakannya. Prasetijo dan Ihalauw (2005), menyebutkan bahwa pencarian internal diperoleh dari kebutuhan dan motivasi, kepribadian, psikografik, perpsepsi, pembelajaran, dan sikap konsumen. Sedangkan pencarian eksternal dapat diperoleh dari keluarga, kelas sosial, budaya dan sub budaya, kelompok acuan dan komunikasi pemasaran. Sepaham dengan hal tersebut, Schiffman dan Kanuk (2000: 7) mengungkapkan bahwa konsumen dapat memperoleh sumber informasi mengenai produk/ jasa dari usaha pemasaran perusahaan (produk, harga, distribusi dan promosi) dan pengaruh sosiologis eksternal (keluarga, teman, tetangga, sumber informal dan non-komersial, kelas sosial, serta keanggotaan budaya dan subbudaya). Komunikasi pemasaran yang diungkapkan Prasetijo dan Ihalauw dan usaha pemasaran perusahaan yang diungkapkan Schiffman dan Kanuk ini, identik dengan konsep marketing stimuli yang diungkapkan oleh Mowen dan Minor, bahwa konsumen dapat memperoleh sumber informasi dari usaha pemasaran perusahaan terkait produk, harga, distribusi dan promosi. Jadi dapat disimpulkan bahwa konsumen dapat memperoleh sumber informasi mengenai kebutuhan produk/ jasa melalui sumber internal, sumber sosiologis eksternal dan usaha komunikasi pemasaran perusahaan yang terkendali (control) berasal dari internal perusahaan dan tidak terkendali (uncontrol) berasal dari luar perusahaan/ eksternal. Uraian ini dapat diperjelas dengan model pada gambar 3.

Dari gambar 3 tersebut, khususnya pada bagan komunikasi pemasaran, sumber informasi terkontrol (control) yang diperoleh konsumen, cenderung mudah untuk dikendalikan oleh organisasi/ perusahaan karena media komunikasi pemasaran, dibuat dan disediakan oleh pihak internal perusahaan. Sedangkan komunikasi pemasaran eksternal merupakan jenis komunikasi pemasaran yang pesannya berasal dari luar organisasi dan cenderung tidak mudah dikendalikan oleh organisasi/ perusahaan (Lovelock 2014: 203). Melalui penjelasan tersebut dapat ditarik kesimpulan bahwa tentunya konsumen akan lebih percaya kepada informasi yang bersifat tidak mudah dikendalikan organisasi atau komunikasi eksternal, karena informasi yang mudah dikendalikan ditakutkan hanya berpihak pada perusahaan tertentu dan 
dikhawatirkan nantinya tidak sesuai dengan kondisi yang diharapkan oleh konsumen. Komunikasi eksternal tersebut dapat berupa berita dari mulut ke mulut (WoM), twitter, jejaring sosial, dan liputan media. Dalam konteks penelitian ini, peneliti fokus terhadap word of mouth (WoM). Adapun alasan konsumen memilih WoM, selain dapat dipercaya karena lebih independen, pertimbangan lain yaitu berita yang diperoleh dari WoM merupakan refleksi pengalaman dari pihak yang telah merasakan produk/ jasa yang dikonsumsinya (Lapioyadi, 2008). Dalam bukunya, menurut Arbaniah (2010) word of mouth (WoM) terjadi ketika pelanggan berbicara kepada orang lain mengenai pendapatnya tentang suatu merek, produk, layanan atau perusahaan tertentu kepada orang lain. WoM juga dapat terjadi ketika pihak konsumen yang merasa kurang memperoleh informasi mengenai suatu produk/ jasa, akan bergantung dan mengandalkan berita dari mulut ke mulut untuk membantu dalam pengambilan keputusan. Rekomendasi dari pelanggan lain tersebut sangat dapat mempengaruhi keputusan dalam menggunakan suatu produk/ jasa (Lovelock, 2010). 


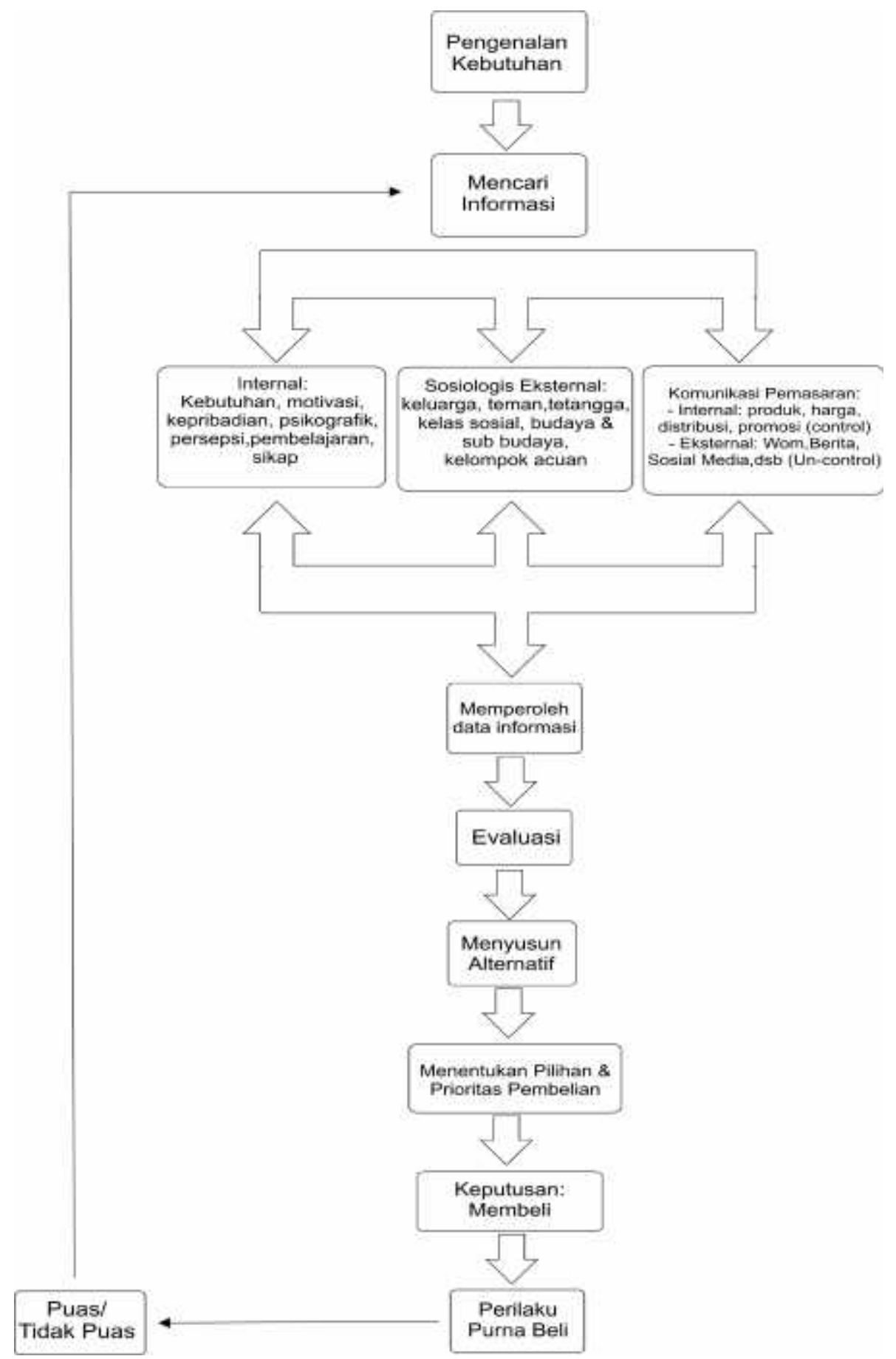

Gambar 3. Proses Pengambilan Keputusan (Diolah dari berbagai sumber)

Penelitian terkait perilaku konsumen, khususnya WoM dan pengambilan keputusan telah banyak dilakukan, beberapa penelitian terkait hal tersebut, dapat dilihat dalam lampiran. Dalam penelitianpenelitian tersebut, peneliti dapat menyimpulkan bahwa terdapat pengaruh atau hubungan yang kuat dan signifikan antara variabel word of mouth dengan keputusan pembelian terhadap produk/ jasa. Dengan kata lain, semakin kuat/ sering berita dari mulut ke mulut didengar, maka semakin kuat keinginan beli atau minat beli terhadap produk atau jasa yang dibicarakan tersebut. 


\section{Minat Beli}

Dalam penelitian yang dilakukan oleh Albarq (2014: 14), teori minat berkunjung dianalogikan sama dengan teori minat beli, dalam penelitian tersebut, minat berkunjung wisatawan disamakan dengan minat pembelian konsumen. Menurut Kotler dan Keller (2003:181) arti minat beli konsumen adalah sebuah perilaku konsumen dimana konsumen mempunyai keinginan dalam membeli atau memilih suatu produk, berdasarkan pengalaman dalam memilih, menggunakan dan mengkonsumsi atau bahkan menginginkan suatu produk. Sedangkan minat beli menurut Howard yang dikutip Durianto dan Liana (2004: 44) mengatakan bahwa minat beli merupakan sesuatu yang berhubungan dengan rencana konsumen untuk membeli produk tertentu serta berapa banyak unit produk yang dibutuhkan pada periode tertentu. Pendapat berbeda diungkapkan oleh Kotler, Bowen dan Makens (1999:156), dimana minat beli timbul setelah adanya proses evaluasi alternatif dan di dalam proses evaluasi, seseorang akan membuat suatu rangkaian pilihan mengenai produk yang hendak dibeli atas dasar merek maupun minat. Pendapat yang lain diungkapkan oleh Sheth, Mittal dan Newman (1999), yang mengungkapkan bahwa minat beli dipengaruhi oleh dua hal yaitu: pengaruh orang lain, dan pengaruh situsional. Pengaruh orang lain dapat berbentuk pengalaman orang lain, rekomendasi dari orang lain, trend yang terjadi, dsb. Sedangkan pengaruh situsional dapat berupa keadaan tak terduga yang mempengaruhi seseorang dilokasi pembelian, seperti contohnya: kondisi keuangan dan alternatif pilihan harga saat membeli, promo, bonus penjualan dilokasi pembelian (contoh: beli 2 gratis 1, beli produk tertentu bonus produk lain,dsb). Lebih dalam lagi Schiffman dan Kanuk (2001: 470-471) mengungkapkan bahwa terdapat 5 indikator dari minat beli, yaitu: 1) tertarik untuk mencari informasi mengenai produk, 2) ingin mengetahui produk, 3) tertarik untuk mencoba, 4) mempertimbangkan untuk membeli, 5) ingin memiliki produk. Dapat disimpulkan bahwa minat beli merupakan rencana untuk memiliki, menginginkan atau mengkonsumsi suatu produk/ jasa dimana rencana tersebut dapat dipengaruhi oleh atribut perusahaan (misal: merk, brand, dsb), faktor internal /diri sendiri (misal: minat/ selera), atau faktor di luar diri sendiri yaitu: pengaruh orang lain seperti rekomendasi dari orang lain, pengalaman orang lain ketika mengkonsumsi sebuah produk,dsb dan pengaruh situsional yang terjadi di lokasi saat hendak melakukan pembelian. Berpatokan pada teori yang diungkapkan Schiffman dan Kanuk tersebut, peneliti menjadikan kelima indikator tersebut sebagai indikator penelitian ini.

\section{Hubungan WoM terhadap Minat Beli}

Hampir sebagian besar proses komunikasi yang terjadi antar manusia dilakukan melalui mulut ke mulut. Proses komunikasi ini terjadi ketika seseorang berbicara, saling bertukar pikiran, saling tukar informasi dan proses komunikasi lainnya. Dalam proses komunikasi dari mulut ke mulut inilah pencarian informasi konsumen terhadap produk atau jasa juga terjadi. Dalam komunikasi tersebut pastilah terjadi tukar informasi yang bersifat positif maupun bersifat negatif. Oleh karena itu, Hughes (2005) mengkategorikan word of mouth dalam dua jenis yaitu word of mouth positif dan word of mouth negatif. Word of mouth 
positif adalah penyampaian informasi dari mulut ke mulut yang dilakukan oleh individu yang satu ke individu lain berdasarkan atas pengalaman yang bersifat positif terhadap suatu produk, jasa, maupun perusahaan. Sementara itu, komunikasi word of mouth negatif merupakan proses interaksi dari mulut ke mulut yang didasarkan pada pengalaman negatif yang diperoleh dari individu yang satu ke individu yang lain terhadap suatu produk, jasa, atau perusahaan. Pengalaman yang bersifat positif disinyalir sebagai pengalaman yang diperoleh seseorang baik langsung maupun tidak langsung terhadap penggunaan suatu produk, jasa, atau perusahaan disertai dengan kepuasan atau terpenuhinya harapan individu tersebut. Sebaliknya, pengalaman yang bersifat negatif merupakan pengalaman yang diperoleh individu baik secara langsung maupun tidak langsung yang tidak disertai dengan kepuasan. Dari word of mouth positif maupun word of mouth negatif inilah konsumen dengan sendirinya melakukan evaluasi atas produk, jasa atau perusahaan. Menurut Dahara (2008), pada umumnya pengaruh word of mouth negatif lebih besar dibanding word of mouth positif. Selain itu word of mouth negatif juga relatif lebih cepat menyebar dibanding dengan word of mouth positif. Dalam penelitian yang dilakukan Richin (1984), word of mouth negatif terjadi dikarenakan 4 hal, yaitu: pengurangan kecemasan konsumen dengan cara membagi pengalaman kepada orang lain (kataris), usaha untuk mencengah orang lain bernasib sama (altruism), usaha mempengaruhi orang untuk menentang suatu produk (vengeance), dan dalam rangka mendapat informasi dimana yang bersangkutan bisa memperoleh bantuan dan bisa menyelesaikannya.

Terkait dengan minat beli, menurut Susanti (2009: 1) word of mouth yang bersifat negatif dengan menyampaikan ketidakpuasan, dapat berakibat pihak lain tidak berminat membeli produk tersebut. Sebaliknya, word of mouth positif yang membawa pesan kepuasan terhadap produk/ jasa, dapat meningkatkan minat beli seseorang bahwa pengambilan keputusan untuk menggunakan sebuah produk atau jasa. Sehingga secara umum dapat disimpulkan bahwa word of mouth atau berita dari mulut ke mulut mampu mempengaruhi minat atau keputusan beli seseorang. Dalam penelitian ini, peneliti mencoba membuat hipotesis penelitian sebagai berikut:

H0: Tidak terdapat pengaruh antara word of mouth yang diterima dengan minat berkunjung ke Perpustakaan Daerah Salatiga

H1 : Terdapat pengaruh antara word of mouth yang diterima dengan minat berkunjung ke Perpustakaan Daerah Salatiga

Word of mouth akan diukur berdasarkan volume dan dispersion. Godes dan Mazlin (2004), mengatakan bahwa:

- Volume merupakan eleman pengukuran yang menyatakan seberapa banyak word of mouth yang terjadi, atau dapat dianalogikan juga dengan frekuensi yaitu seberapa sering orang membicarakan atau merekomendasikan produk/ jasa. 
- Dispersion, didefinisikan sebagai tingkat dimana percakapan mengenai produk/ jasa mengambil tempat di dalam komunikasi yang luas, atau dapat diartikan sebagai jangkauan, yaitu seberapa banyak orang berbeda yang membicarakan sebuah produk/ jasa.

Dari penjelasan tersebut, diperoleh gambaran model sebagai berikut:

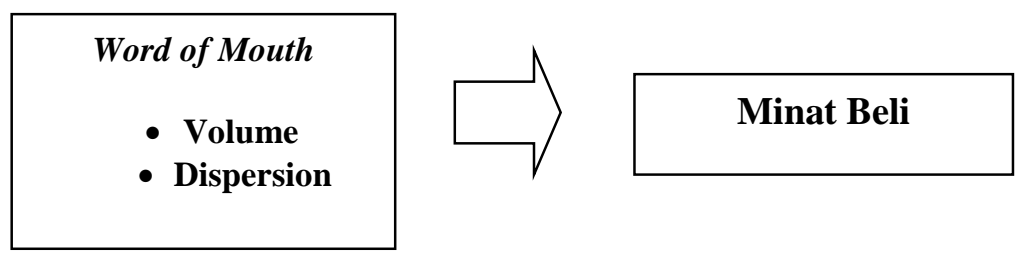

Gambar 4. Model Penelitian

\section{Operasional Konsep}

Untuk menyusun kuesioner bagi responden, peneliti menjabarkan variabel word of mouth dan minat beli dengan rincian sebagai berikut:

Tabel 1. Operasionalisasi Konsep

\begin{tabular}{|c|c|c|c|}
\hline Variabel & Definisi & Indikator & Kategori \\
\hline $\begin{array}{l}\text { Word } \\
\text { mouth }\end{array}$ & 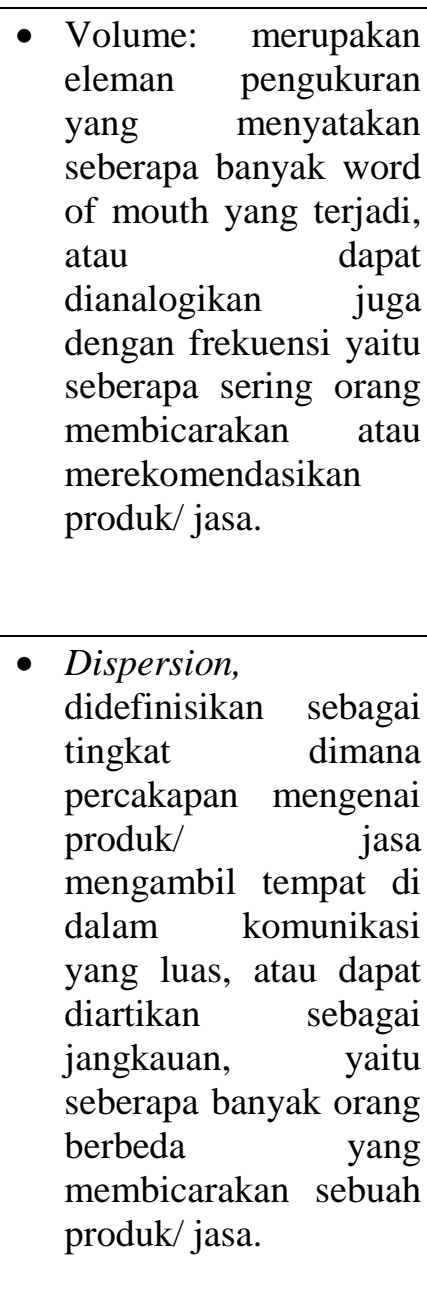 & $\begin{array}{l}\text { - Sering } \\
\text { PERPUSDA Salatiga } \\
\text { dalam percakapan sehari- } \\
\text { hari. } \\
\text { - Sering melakukan diskusi } \\
\text { mengenai PERPUSDA } \\
\text { Salatiga dengan orang lain. } \\
\text { - Sering mendapat } \\
\text { rekomendasi unt ke } \\
\text { berkunjung untuk } \\
\text { PERPUSDA Salatiga } \\
\text { - Sering mendengar } \\
\text { PERPUSDA Salatiga dari } \\
\text { orang lain. } \\
\text { - Mendengar PERPUSDA } \\
\text { Salatiga dari keluarga. } \\
\text { - Mendengar PERPUSDA } \\
\text { Salatiga dari teman } \\
\text { kampus/ kantor } \\
\text { - Mendengar PERPUSDA } \\
\text { Salatiga dari tetangga. } \\
\text { - Mendengar PERPUSDA } \\
\text { Salatiga dari orang yang } \\
\text { pernah berkunjung ke } \\
\text { perpustakaan tersebut. } \\
\text { - Mendengar PERPUSDA } \\
\text { Salatiga dari orang yang } \\
\text { profesinya/ pekerjaannya } \\
\text { berbeda denga saya. }\end{array}$ & $\begin{array}{c}\text { STS-SS } \\
1-6\end{array}$ \\
\hline
\end{tabular}




\begin{tabular}{|c|c|c|c|}
\hline & & $\begin{array}{l}\text { - Mendengar PERPUSDA } \\
\text { Salatiga dari orang yang } \\
\text { memiliki status yang } \\
\text { berbeda dengan saya. }\end{array}$ & \\
\hline $\begin{array}{l}\text { Minat Beli } \\
\text { (Shiffman } \\
\text { \& Kanuk) }\end{array}$ & $\begin{array}{l}\text { Mengungkapkan bahwa } \\
\text { terdapat } 5 \text { indikator dari } \\
\text { minat beli, yaitu: } \\
\text { - Tertarik untuk mencari } \\
\text { informasi mengenai } \\
\text { produk, } \\
\text { - Ingin } \\
\text { produk, mengetahui } \\
\text { - Tertarik } \\
\text { mencoba, } \\
\text { - Mempertimbangkan } \\
\text { - } \text { Intuk membeli, } \\
\text { Ingin memiliki produk }\end{array}$ & $\begin{array}{l}\text { - Tertarik mencari informasi } \\
\text { mengenai PERPUSDA } \\
\text { Salatiga. } \\
\text { - Ingin mengetahui fasilitas } \\
\text { yang disediakan } \\
\text { PERPUSDA Salatiga } \\
\text { - Tertarik untuk mencoba } \\
\text { berkunjung } \\
\text { PERPUSDA Salatiga ke } \\
\text { - Mempertimbangkan untuk } \\
\text { berkunjung } \\
\text { PERPUSDA Salatiga } \\
\text { - Ingin berkunjung ke } \\
\text { PERPUSDA Salatiga }\end{array}$ & $\begin{array}{c}\text { STS-SS } \\
1-6\end{array}$ \\
\hline
\end{tabular}

\section{Metode Penelitian}

Pendekatan penelitian ini menggunakan pendekatan kuantitatif. Konsep yang dikemukakan akan disusun menjadi hipotesis, kemudian sampel yang diambil digunakan untuk menguji hipotesis yang ada. Metode pengambilan sampel yang digunakan adalah non probability sampling, yaitu teknik yang tidak memberikan peluang/ kesempatan sama bagi setiap unsur atau anggota populasi untuk dipilih menjadi sampel (Sugiyono: 2003). Sedangkan teknik penentuan sampel menggunakan sampling insidental. Menurut Sugiyono (2013: 85) sampling insidental adalah pengambilan sampel berdasarkan kebetulan atau siapa saja yang kebetulan bertemu dengan peneliti dan dirasa cocok untuk dijadikan sampel. Ukuran sampel mengacu pada Roscoe (1975), menyarankan bahwa besar jumlah sampel yang layak adalah 30500. Dalam penelitian ini, peneliti menggunakan 100 sampel dengan pertimbangan 100 sampel dinilai cukup ideal dan mampu mewakili populasi dalam penelitian ini, selain itu keterbatsan dana dan waktu menjadi pertimbangan lain.

Pada penelitian ini varibel bebas nya adalah word of mouth, sedangkan variable terikatnya adalah minat beli (dalam hal ini minat berkunjung). Variabel word of mouth dan minat beli diukur dengan enam point skala derajat kesetujuan, yaitu $1=$ Sangat Tidak Setuju, $2=$ Tidak Setuju, $3=$ Agak Tidak Setuju, $4=$ Agak Setuju, 5= Setuju, 6= Sangat Setuju. Penggunaan Skala Likert dengan ukuran interval skala 6 dengan tujuan untuk menghindari kecenderungan responden menjawab ragu-ragu atau netral.

Uji Validitas dalam penelitian ini dilakukan dengan cara corrected item to total correlation yaitu melakukan korelasi antar skor butir pertanyaan dengan total konstruk atau variabel melalui program SPSS 22.00. Dalam pengujian validitas ini digunakan kriteria dari Anzwar (2005) dimana item valid jika korelasi antara item tersebut dengan skor totalnya $\geq 0,25$. Uji reliabilitas adalah alat untuk mengukur 
suatu kuesioner yang merupakan indikator dari variabel atau konstruk. Suatu kuesioner dikatakan reliabel atau handal jika jawaban seseorang terhadap pernyataan adalah konsisten atau stabil dari waktu ke waktu. Pengujian reliabel dilakukan melalui program SPSS, jika Cronbach Alpha $>0.6$ konstruk atau variabel dikatakan reliabel (Nunnally, 1967).

\section{Hasil dan Pembahasan}

Penelitian ini dilakukan melalui dua tahap yaitu tahap pretest dan tahap penelitian utama. Tahap pretest dilakukan dengan membagikan 30 kuesioner, untuk penelitian utama peneliti menentukan sampel sebesar 100 kuesioner untuk memperoleh data. Sebelum kuesioner penelitian utama disebarkan, peneliti terlebih dahulu melakukan uji validitas dan reliabilitas terhadap 30 orang responden. Berdasarkan hasil uji tersebut, semua item kuesioner penelitian utama sudah valid dan reliabel. Valid dalam penelitian ini artinya semua item pertanyaan dari variabel yang diuji memiliki nilai lebih dari 0,25 sehingga masuk dalam kriteria valid. Dalam uji reliabilitas yang dilakukan melalui program SPSS, diperolah nilai Cronbach Alpha sebagai berikut: 0,775 untuk dimensi volume; 0,635 untuk dimensi dispersion dan 0,790 untuk variabel minat berkunjung, dimana semuanya lebih besar dari 0,6 sehingga konstruk atau variabel dapat disimpulkan reliabel (Nunnally, 1967).

Terdapat dua variabel dalam penelitian ini, yaitu variabel word of mouth yang diwakili oleh dimensi volume dan dispersion serta variabel minat berkunjung. Dimensi volume memiliki 4 item pernyataan, dimensi dispersion memiliki 6 item pernyataan, dan variabel minat kunjung memiliki 9 item pernyataan. Berikut ini dijelaskan lebih rinci analisis dan bahasan dari data yang telah dikumpulkan dan diolah oleh peneliti. Berdasarkan jenis kelamin diperoleh 54 persen responden pria dan sisanya responden wanita. Usia 18-22 menduduki tingkat tertinggi dalam hal kunjungan, hal ini diduga karena pada usia tersebut merupakan usia produktif pendidikan atau usia pelajar, sehingga mereka membutuhkan informasi dan ilmu pengetahuan untuk mendukung pendidikan mereka. Mayoritas responden berasal dari kota Salatiga dan sekitarnya, diduga karena sudah cukup mengenal Perpustakaan dan Arsip Daerah sebagai tujuan dalam mencari informasi terkait ilmu pengetahuan atau bahkan sebagai tujuan wisata yang murah. Diperoleh fakta bahwa sebagian besar berstatus sebagai pelajar/ mahasiswa yaitu sebesar 73 persen responden. Hal ini merupakan hal yang wajar dikarenakan pelajar/ mahasiswa sangat membutuhkan fasilitas khususnya buku-buku atau fasilitas wifi internet yang disediakan oleh Perpustakaan dan Arsip Daerah Salatiga guna mencari informasi yang dibutuhkan terkait dengan tugas yang diberikan. Secara lebih rinci data karakteristik responden dapat dilihat pada tabel berikut: 
Tabel 2. Karakteristik Responden

\begin{tabular}{|c|c|c|c|}
\hline $\begin{array}{c}\text { Karakteristik } \\
\text { Responden }\end{array}$ & $\begin{array}{c}\text { Variabel } \\
\text { Karakteristik }\end{array}$ & $\begin{array}{c}\text { Jumlah } \\
\text { Responden }\end{array}$ & Persen \\
\hline Frekuensi & Kadang-kadang & 54 & $54 \%$ \\
\hline Pembelian & $\begin{array}{l}\text { Cukup Sering } \\
\text { Sering sekali }\end{array}$ & 46 & $46 \%$ \\
\hline Jenis Kelamin & $\begin{array}{l}\text { Pria } \\
\text { Wanita }\end{array}$ & $\begin{array}{l}54 \\
46\end{array}$ & $\begin{array}{l}54 \% \\
46 \%\end{array}$ \\
\hline Usia & $\begin{array}{l}18-22 \\
23-27 \\
28-32 \\
33-37 \\
38-41 \\
>42\end{array}$ & $\begin{array}{l}77 \\
6 \\
4 \\
2 \\
6 \\
5\end{array}$ & $\begin{array}{l}77 \% \\
6 \% \\
4 \% \\
2 \% \\
6 \% \\
5 \%\end{array}$ \\
\hline Kota Asal & $\begin{array}{l}\text { Salatiga } \\
\text { Semarang } \\
\text { Solo } \\
\text { Yogyakarta } \\
\text { Surabaya } \\
\text { Lainnya }\end{array}$ & $\begin{array}{c}45 \\
19 \\
4 \\
- \\
- \\
32\end{array}$ & $\begin{array}{c}45 \% \\
19 \% \\
4 \% \\
- \\
- \\
32 \%\end{array}$ \\
\hline Pendidikan & $\begin{array}{l}\text { SD } \\
\text { SLTP } \\
\text { SLTA } \\
\text { D3 } \\
\text { S1 } \\
\text { S2 } \\
\text { S3 } \\
\text { Lainnya }\end{array}$ & $\begin{array}{c}1 \\
- \\
71 \\
3 \\
16 \\
8 \\
-\end{array}$ & $\begin{array}{c}1 \% \\
71 \% \\
3 \% \\
16 \% \\
8 \% \\
-\end{array}$ \\
\hline $\begin{array}{l}\text { Rata-rata } \\
\text { Penghasilan }\end{array}$ & $\begin{array}{l}<1 \text { jt } \\
1-2 \text { juta } \\
2-3 \text { juta } \\
3-4 \text { juta } \\
4-5 \text { juta } \\
>5 \text { juta }\end{array}$ & $\begin{array}{l}71 \\
16 \\
4 \\
4 \\
3 \\
2\end{array}$ & $\begin{array}{l}71 \% \\
16 \% \\
4 \% \\
4 \% \\
3 \% \\
3 \% \\
\end{array}$ \\
\hline $\begin{array}{l}\text { Jenis } \\
\text { Pekerjaan }\end{array}$ & $\begin{array}{l}\text { Tidak bekerja } \\
\text { Pelajar/ Mahasiswa } \\
\text { Pegawai Swasta } \\
\text { Pegawai Negeri } \\
\text { Wiraswasta } \\
\text { Lainnya }\end{array}$ & $\begin{array}{c}- \\
73 \\
11 \\
5 \\
- \\
6\end{array}$ & $\begin{array}{c}- \\
73 \% \\
11 \% \\
5 \% \\
- \\
6 \%\end{array}$ \\
\hline
\end{tabular}

Berikut ini hasil analisis deskriptif terhadap variable word of mouth yang diwakili oleh dimensi volume dan dispersion serta variabel minat berkunjung. 
Tabel 3. Hasil Analisis Deskriptif Dimensi Volume

\begin{tabular}{|c|c|c|c|c|c|c|c|}
\hline Skor & Kriteria & $\mathbf{F}$ & $\%$ & Min & Max & Mean & SD \\
\hline $1,00<\mathrm{x} \leq 1,80$ & $\begin{array}{c}\text { Sangat } \\
\text { tidak sering }\end{array}$ & 1 & 1 & \multirow{5}{*}{7,00} & \multirow{5}{*}{24,0} & \multirow{5}{*}{16,54} & \multirow{5}{*}{3,95536} \\
\hline $1,81<\mathrm{x} \leq 2,60$ & Tidak sering & 8 & 8 & & & & \\
\hline $2,61<x \leq 3,40$ & Cukup sering & 10 & 10 & & & & \\
\hline $3,41<x \leq 4,20$ & Sering & 24 & 24 & & & & \\
\hline $4,21 \leq \mathrm{x} \leq 5,00$ & Sangat sering & 57 & 57 & & & & \\
\hline TOTAL & & 100 & 100 & & & & \\
\hline
\end{tabular}

Hasil tabel diatas dapat disimpulkan bahwa pada dimensi volume diperoleh presentase tertinggi yaitu 57 persen, yang diartikan bahwa sebagian besar pengunjung sering membicarakan atau merekomendasikan Perpustakaan Daerah Salatiga kepada orang lain. Disimpulkan bahwa telah terjadi berita dari mulut ke mulut (WOM) dengan frekuensi yang sangat sering atas keberadaan Perpustakaan dan Arsip Daerah Salatiga.

Tabel 4. Deskriptif Statistik Dimensi Volume

\begin{tabular}{cccc}
\hline & Mean & Std. Deviation & $\mathrm{N}$ \\
\hline $\mathrm{x} 1$ & 4,4200 & 1,22417 & 100 \\
\hline $\mathrm{x} 2$ & 3,4800 & 1,44586 & 100 \\
\hline $\mathrm{x} 3$ & 4,1700 & 1,27172 & 100 \\
\hline $\mathrm{x} 4$ & 4,4700 & 1,15867 & 100 \\
\hline Total & 16,5400 & 3,95536 & 100 \\
\hline
\end{tabular}

Pada tabel 4, diperoleh nilai mean sebesar 4,47 untuk item 4 yang berarti bahwa sebagian besar responden sependapat bahwa sering mendengar mengenai Perpustakaan dan Arsip Daerah Salatiga melalui orang lain. Ini menandakan bahwa orang lain merupakan salah satu elemen penting dalam merekomendasikan produk/ layanan jasa, karena lebih dipercaya daripada jika hal tersebut dilakukan oleh pihak instansi/ perusahaan.

Tabel 5. Hasil Analisis Deskriptif Dimensi Dispersion

\begin{tabular}{|c|c|c|c|c|c|c|c|}
\hline Skor & Kriteria & $\mathbf{F}$ & $\%$ & Min & Max & Mean & SD \\
\hline $1,00<x \leq 1,80$ & $\begin{array}{c}\text { Sangat } \\
\text { tidak banyak }\end{array}$ & - & - & \multirow{5}{*}{12} & \multirow{5}{*}{34} & \multirow{5}{*}{22,76} & \multirow{5}{*}{4,91775} \\
\hline $1,81<\mathrm{x} \leq 2,60$ & Tidak banyak & 8 & 8 & & & & \\
\hline $2,61<\mathrm{x} \leq 3,40$ & Cukup banyak & 21 & 21 & & & & \\
\hline $3,41<x \leq 4,20$ & Banyak & 41 & 41 & & & & \\
\hline $4,21 \leq x \leq 5,00$ & Sangat banyak & 30 & 30 & & & & \\
\hline
\end{tabular}

Pada tabel 5, diperoleh nilai tertinggi sebesar 41 persen dimana tingkat dimana percakapan mengenai keberadaan Perpustakan dan Arsip Daerah Salatiga diartikan memiliki jangkauan yang luas, 
karena hampir sebagian besar orang, membicarakan keberadaan Perpustakaan dan Arsip Daerah Salatiga.

Tabel 6. Deskriptif Statistik Dimensi Dispersion

\begin{tabular}{lrrr}
\hline & Mean & Std. Deviation & N \\
\hline $\mathrm{x} 1$ & 3,5200 & 1,64826 & 100 \\
\hline $\mathrm{x} 2$ & 4,6300 & 1,24442 & 100 \\
\hline $\mathrm{x} 3$ & 2,7800 & 1,45352 & 100 \\
\hline $\mathrm{x} 4$ & 4,8400 & 1,10755 & 100 \\
\hline $\mathrm{x} 5$ & 3,3900 & 1,43474 & 100 \\
\hline $\mathrm{x} 6$ & 3,6000 & 1,31041 & 100 \\
\hline Total & 22,7600 & 4,91775 & 100 \\
\hline
\end{tabular}

Pada tabel 6, diperoleh nilai mean sebesar 4,84 untuk item 4 yang berarti bahwa banyaknya tingkat komunikasi yang terjadi disebabkan sebagian orang memperoleh informasi mengenai keberadaan Perpustakan dan Arsip Daerah Salatiga melalui orang yang pernah berkunjung ke tempat tersebut. Lebih dalam lagi nilai mean terbesar kedua adalah sebesar 4,63 yaitu informasi tersebut diperoleh dari teman kampus yang pernah berkunjung ke Perpustakan dan Arsip Daerah Salatiga, hal ini sangat berkaitan erat dengan hasil analisa dari karakteristik responden dimana sebagian besar pengunjung merupakan mahasiswa (73 persen).

Tabel 7. Hasil Analisis Deskriptif Variabel Minat Berkunjung

\begin{tabular}{|c|c|c|c|c|c|c|c|}
\hline Skor & Kriteria & $\mathbf{F}$ & $\begin{array}{c}\text { pers } \\
\text { en }\end{array}$ & Min & Max & Mean & SD \\
\hline $1,00<\mathrm{x} \leq 1,80$ & $\begin{array}{c}\text { Sangat } \\
\text { tidak berminat }\end{array}$ & - & - & \multirow{5}{*}{21} & \multirow{5}{*}{54} & \multirow{5}{*}{40,25} & \multirow{5}{*}{5,95161} \\
\hline $1,81<x \leq 2,60$ & Tidak berminat & 1 & $1 \%$ & & & & \\
\hline $2,61<x \leq 3,40$ & Cukup berminat & 6 & $6 \%$ & & & & \\
\hline $3,41<x \leq 4,20$ & Berminat & 23 & $23 \%$ & & & & \\
\hline $4,21 \leq \mathrm{x} \leq 5,00$ & Sangat berminat & 70 & $70 \%$ & & & & \\
\hline
\end{tabular}


Tabel 8. Deskriptif Statistik Variabel Minat Berkunjung

\begin{tabular}{lrrr}
\hline & Mean & \multicolumn{1}{c}{ Std. Deviation } & N \\
\hline $\mathrm{x} 1$ & 4,9000 &, 87039 & 100 \\
\hline $\mathrm{x} 2$ & 4,5000 &, 96922 & 100 \\
\hline $\mathrm{x} 3$ & 4,3200 & 1,20504 & 100 \\
\hline $\mathrm{x} 4$ & 4,5000 & 1,08711 & 100 \\
\hline $\mathrm{x} 5$ & 3,9200 & 1,31564 & 100 \\
\hline $\mathrm{x} 6$ & 4,9000 & 1,04929 & 100 \\
\hline $\mathrm{x} 7$ & 4,0300 & 1,19304 & 100 \\
\hline $\mathrm{x} 8$ & 4,5000 &, 92660 & 100 \\
\hline $\mathrm{x} 9$ & 4,5600 & 1,02809 & 100 \\
\hline Total & 40,2500 & 5,95161 & 100 \\
\hline
\end{tabular}

Pada tabel 7, diperoleh nilai tertinggi sebesar 70 persen dengan kriteria sangat banyak yang artinya, sebagian besar responden Perpustakaan dan Arsip Daerah Salatiga ketika memperoleh berita dari orang lain, merasa tertarik, ingin mengetahui lebih lagi bahkan mempertimbangkan untuk berkunjung. Hal ini dapat dilihat pada tabel 8, dimana nilai mean minat berkunjung sebesar 4,90 untuk item 1 dan item 6 yang berarti bahwa sebagian besar pengunjung berminat datang ke Perpustakaan dan Arsip Daerah Salatiga dikarena tertarik mencari informasi mengenai buku-buku yang tersedia. Selain itu, pemustaka juga merasa tertarik untuk memanfaatkan fasilitas wifi yang tersedia di Perpustakaan dan Arsip Daerah Salatiga ketika mencari informasi yang diinginkan.

\section{Pengaruh Word of Mouth terhadap Minat Berkunjung}

Penelitian yang dilakukan melakukan pengukuran pengaruh word of mouth terhadap minat berkunjung. Dalam hal ini, word of mouth sebagai variabel independent atau bebas yang dibagi menjadi dimensi volume dan dispersion. Minat berkunjung dikategorikan sebagai variabel dependen atau tetap yang diterjemahkan langsung dalam indikator-indikator.

Tabel 9. Tabel Hasil Regresi

\begin{tabular}{|c|c|c|c|c|c|}
\hline Model & $\mathrm{R}$ & R Square & $\begin{array}{c}\text { Adjusted R } \\
\text { Square }\end{array}$ & $\begin{array}{l}\text { Std. Error of the } \\
\text { Estimate }\end{array}$ & Durbin-Watson \\
\hline 1 &, $473^{\mathrm{a}}$ & ,224 & ,216 & 5,26920 & 1,914 \\
\hline
\end{tabular}

Pada tabel 9 diperoleh nilai koefisien regresi antara variabel word of mouth dan variabel minat berkunjung adalah 0,473 yang artinya hal ini menunjukkan bahwa pengaruh word of mouth terhadap minat berkunjung adalah positif yang berarti semakin banyak word of mouth maka semakin besar minat berkunjung seseorang. Sedangkan nilai R square atau koefisien determinasi adalah sebesar 0.224. Ini berarti 22,4 persen minat berkunjung ke Perpustakaan dan Arsip Daerah Salatiga dipengaruhi oleh word of mouth. Sisanya 77,6 persen minat berkunjung ke Perpustakaan dan Arsip Daerah Salatiga dipengaruhi 
oleh faktor lain. Peneliti menduga faktor lain yang dapat mempengaruhi minat berkunjung selain word of mouth (wom) antara lain faktor promosi melalui brosur, publikasi/ public relation, lomba yang diadakan disekitar lokasi, website, pameran buku, bedah buku ,dsb. Pada tabel nilai Durbin-Watson yang diperoleh adalah sebesar 1,914, hal ini menunjukkan bahwa variabel word of mouth terhadap minat berkunjung pada Perpustakaan dan Arsip Daerah Salatiga sudah termasuk variabel yang independen, mengingat syarat yang ditentukan adalah 1.5 hingga 2.5 .

Dari hasil uraian analisis, maka diperoleh temuan bahwa word of mouth merupakan faktor yang cukup berpengaruh signifikan terhadap minat berkunjung. Pengalaman-pengalaman yang pernah dialami oleh pemustaka (konsumen) dapat menjadi informasi bagi calon pemustaka berikutnya melalui word of mouth yang terjadi. Sehingga secara umum dapat disimpulkan bahwa word of mouth atau berita dari mulut ke mulut mampu mempengaruhi minat atau keputusan beli (berkunjung) seseorang, terhadap produk atau jasa yang ditawarkan oleh pasar. Terkait dengan hal ini, penelitian yang dilakukan oleh Muniningsih dan Prasetyo (2014) terhadap sektor jasa wisata, menunjukkan bahwa variabel word of mouth communication berpengaruh signifikan terhadap keputusan pembelian, secara simultan maupun parsial. Sementara itu senada dengan penelitian terkait minat berkunjung yang dilakukan oleh Aprilia, Kumadji dan Kusumawati (2015), menunjukkan bahwa word of mouth memberikan dampak yang signifikan terhadap minat berkunjug seseorang ke sebuah tempat wisata. Dijelaskan pula pengunjung memiliki keinginan lebih dalam untuk mencari informasi mengenai tempat wisata tersebut melalui word of mouth yang berasal dari orang lain seperti dari keluarga, teman dekat, mitra kerja, tetangga, dan bahkan melalui orang yang memiliki pengetahuan mendalam tentang tempat wisata tersebut. Dengan demikian hasil penelitian ini semakin memperkuat penelitian yang telah dilakukan sebelumnya, dimana word of mouth menunjukkan memiliki pengaruh yang signifikan terhadap minat berkunjung.

\section{Simpulan}

1. Terkait dengan dimensi volume, disimpulkan bahwa telah terjadi berita dari mulut ke mulut (WOM) dengan frekuensi yang sangat sering (57\%) atas keberadaan Perpustakaan dan Arsip Daerah Salatiga. Dalam hal ini, pemustaka yang pernah berkunjung ke Perpustakaan dan Arsip Daerah Salatiga diduga merekomendasikan keberadaan Perpustakaan dan Arsip Daerah Salatiga kepada orang lain.

2. Pada dimensi dispersion yang diteliti, percakapan mengenai Perpustakan dan Arsip Daerah Salatiga disimpulkan memiliki jangkauan yang luas yaitu sebesar $41 \%$. Informasi mengenai keberadaan Perpustakan dan Arsip Daerah Salatiga tersebut tersebar luas melalui mahasiswa yang pernah berkunjung ke Perpustakan dan Arsip Daerah Salatiga.

3. Minat untuk berkunjung ke Perpustakan dan Arsip Daerah Salatiga dikategorikan sangat besar yaitu sebesar $70 \%$. Minat berkunjung tersebut disebabkan ketertarikan terhadapi informasi mengenai bukubuku yang tersedia dan fasilitas wifi yang tersedia di Perpustakaan dan Arsip Daerah Salatiga. 
4. Terdapat pengaruh yang signifikan antara berita dari mulut ke mulut ( word of mouth) dengan minat berkunjung ke Perpustakan dan Arsip Daerah Salatiga, walaupun ditemukan juga faktor - faktor lain yang mungkin juga dapat mempengaruhi minat berkunjung seperti promosi melalui brosur, publikasi/ public relation, lomba yang diadakan di lokasi perpustakaan, website, pameran buku, bedah buku ,dsb.

\section{Daftar Pustaka}

Albarq, Abbas N. 2014, "Measuring the Impacts of Online Word of Mouth on Tourists' Attitude and Intentions to Visit Jordan: An Empirical Study”, International Business Research, vol. 7, no.1.

Arbainah, Siti. 2010, Studi tentang Words of Mouth (WOM) Positif pada Bisnis Ritel Pasar Modern (Kasus Empiris pada Minimarket Alfamart dan Indomaret di Kota Semarang), Tesis: Program Studi Magister Manajemen Program Pasca Sarjana, Universitas Diponegoro Semarang.

Bansal, H.S.; Voyer, P.A.2000, World of Mouth Processes Within A Services Purchase Decision Context, Journal of Service Research, vol. 3, no.2, p.166-177.

Dahara, Doni Wirawan. 2008, Rangkuman Word of Mouth. Diakses tanggal 12 Agustus 2016, http//www.donidw.wordpres.com.

2015, Data Statistik Pengunjung, Anggota dan Jumlah Koleksi Perpustakaan Umum dan Arsip Kota Salatiga Tahun 2015.

Durianto, D dan C. Liana. 2004, Analisis Efektivitas Iklan Televisi Softener Soft \& Fresh di Jakarta dan Sekitarnya dengan Menggunakan Consumen Decision Model, Jurnal Ekonomi Perusahaan, 11 (1): 35-55.

Godes,David dan Dina Mayzlin. 2004, Using Online Conversations to Study Word of Mouth Communication, Marketing Science vol. 23, no. 4, Fall 2004, pp. 545-560.

Hasan, Ali. 2010, Marketing dari Mulut ke Mulut, Yogyakarta: Media Pressindo.

Hermawan, Agus. 2012, Komunikasi Pemasaran. Jakarta, Erlangga

Hermawan, Rachman dan Zulfikar Zen. 2006, Etika Kepustakawanan: Suatu Pendekatan terhadap Profesi dan Kode Etik Pustakawan Indonesia, Jakarta: Sagung Seto.

Hughes, Mark. 2005, Buzz Marketing, Jakarta: Gramedia Pustaka Utama.

Kotler, P., dan Keller, K.L. 2003, Manajemen Pemasaran, Edisi 12, Cetakan III, Alih Bahasa oleh Benyamin Molan.

Kotler, Phillip, Bowen, J dan Makens, J. 1999, Marketing for Hospitality and Tourism. Upper Saddle River, NJ Prentice Hall

Kotler, Phillip dan Keller. 2007, Manajemen Pemasaran, edisi 12, Jilid 1, Jakarta: PT.Indeks. 
Kumala, Octaviantika Benazir. 2012, Pengaruh Word of Mouth terhadap Minat Beli Konsumen pada Tune Hotels Kuta-Bali, Skripsi: Universitas Indonesia, Fakultas Ilmu Sosial dan Politik Departemen Ilmu Administrasi.

Kurnia, Marlina, Rochiyati M dan Agung Dhany Prasetyo.2014, Pengaruh Word of Mouth Communication terhadap Keputusan Konsumen UMKM di Area Wisata Kuliner Badaan Kota Magelang, Universitas Muhammadiyah Magelang.

Lapiyoadi, Rambat. 2008, Manajemen Pemasaran Jasa, Jakarta: Salemba Empat

Lupiyoadi, Rambat. 2013, Manajemen Pemasaran Jasa: Berbasis Kompetensi, Jakarta: Salemba Empat.

Lovelock, Christopher. 2010, Pemasaran Jasa Manusia, Teknologi, Strategi Perspektif Indonesia, Jakarta: Erlangga

Marsha, L.Richin. 1984, Word of Mouth Communication as Negative Information, Advances in Consumer Research, vol. 11, ed. 697-702.

Mowen, John C dan Michael S. Minor. 2002, Perilaku Konsumen, Jakarta: Erlangga.

Nunnally, J.C. 1967, Psychometric Theory, New York: McGraw-Hill.

O'Leary, Steve dan Sheehan. 2008, Building Buzz to Beat the Big Boys Word of Mouth Marketing for Small Bussiness.United States of America: Praeger Publishers, 88 Post Road West, Westport, CT 06881 An imprint of Greenwood Publishing Group, Inc.

Prasetijo, Ristiyanti dan John J.O.I Ihalauw. 2005, Perilaku Konsumen, Yogyakarta: Penerbit Andi.

Rangkuti, Freddy. 2009, Strategi Promosi yang Kreatif dan Analisis Kasus Integrated Marketing Communication. Jakarta : PT. Gramedia Pustaka Utama.

Roscoe, J.T. 1975, Fundamental Research Statistic for the Behavioral Sciences (2d.ed), New York: Holt, Rinehart and Winston.

Supriyanto, dkk. 2006, Aksentuasi Perpustakaan dan Pustakawan, Jakarta: Sagung Seto.

Sari, Mustika Viranti. 2012, Pengaruh Electronic Word of Mouth (eWoM) di Social Media Twitter terhadap Minat Beli Konsumen pada Restoran Holycowsteak, Skripsi: Fakultas Ilmu Sosial dan Ilmu Politik, Program Studi Ilmu Administrasi Niaga, Universitas Indonesia.

Silverman, George. 2001, The Secrets of Word of Mouth Marketing: How to Trigger Exponential Slaes Through Runaway Word of Mouth, Amacom, New York. 
Schiffman, Leon G dan Leslie L. Kanuk. 2000, Consumer Behaviour, edisi ke-7, New York: John Wiley \& Son, Inc.

Sheth, Jagdish. N, Banwari Mittal dan Bruce I.Newman. 1999, Costumer Behaviour and Beyond, The Dryden Press, Orlando.

Susanti, Esti. 2009, Word of Mouth Communication, Bandung: Penerbit Alfabeta

Sugiyono. 2003, Statistik untuk Penelitian, Cetakan ke-5, Bandung: Alfabeta

------. 2013, Metode Penelitian Kuantitatif, Kualitatif dan R\&D, Bandung: Alfabeta

Schiffman, Leon G dan Leslie L. Kanuk. 2001, Perilaku Konsumen, Jakarta: Prentice Hall.

Ujianto, Purno. 2013, Strategi Word of Mouth Communication dalam Meningkatkan Minat Menonton Kesenian Banyumasan (Studi Deskriptif Kualitatif pada Paguyuban Seni Sapto Turonggo Joyo Kabupaten Banjarnegara), Skripsi: UIN Sunan Kalijaga, Yogyakarta. Url: Http://Digilib.Uin-Suka.Ac.Id/7419/

Ulumi, Bahrul, Yanis Rusli dan Sri Suharmini W. 2014, Pemasaran Jasa Informasi Perpustakaan, Jakarta: Penerbit Universitas Terbuka 